\title{
STRATEGI COPING DAN DISTORSI KOGNITIF PADA IBU TUNGGAL DI YOGYAKARTA
}

\section{COPING STRATEGY AND COGNITIVE DISTORTION AMONG SINGLE MOTHER IN YOGYAKARTA}

\author{
Malida Fatimah \\ Universitas Mercu Buana Yogyakarta \\ malida.fatimah@gmail.com
}

\begin{abstract}
Abstrak
Penelitian ini bertujuan untuk mengidentifikasi strategi coping dan distorsi kognitif pada ibu tunggal. Metode yang digunakan pada penelitian ini adalah metode survei. Seratus responden dipilih dari komunitas ibu tunggal yang ada di Yogyakarta. Satu set kuesioner yang terdiri dari dua inventori digunakan sebagai instrumen untuk mengumpulkan data. Nilai reliabiitas Cronbach Alpha pada kedua inventori berada pada rentang 0,84 sampai 0,98. Analisis data penelitian ini menggunakan independent t-test, ANOVA, dan korelasi Pearson. Penelitian ini menemukan bahwa strategi coping yang digunakan ibu tunggal adalah menstruktur ulang secara kognitif yang menjadi bagian dari fungsi adaptif dan maladaptif, dan berada pada level menengah; distorsi kognitif pada penelitian ini menunjukkan kecenderungan pada preoccupation with danger (PWD) yang berada pada level kurang mengalami distorsi kognitif. Lebih jauh ditemukan bahwa terdapat hubungan antara distorsi kognitif dan strategi coping. Berdasarkan hasil temuan tersebut, beberapa implikasi dan rekomendasi menjadi bahan diskusi.
\end{abstract}

Kata kunci: strategi coping, distorsi kognitif, ibu tunggal

\begin{abstract}
This study aims to identify coping strategy and cognitive distortion among single mothers. The method used in this study was the survey method. A hundred respondents were selected from the communities of the single mother community in Yogyakarta. A set of questionnaires consisting of two inventories were used as instruments for data collection. The reliability values of Cronbach Alpha for the inventories ranged from 0.84 to 0.98. Independent t-test, ANOVA and Pearson Correlation were used for the data analysis. The study revealed that the coping strategy used by single mothers is cognitive re-structuring which is the part of adaptive and maladaptive function, and is at the middle level; Cognitive distortion in this study shows a tendency towards the preoccupation with danger (PWD) which is at the level of less experienced cognitive distortion. Furthermore, it was found that there was no significant difference in coping strategies among groups of different economic statuses, occupations, and reasons for being single. The results further revealed that there was a relationship between coping strategy and cognitive distortion. Based on the findings, several implications and recommendations were discussed.
\end{abstract}

Keyword: coping strategy, cognitive distortion, single mother

\section{PENDAHULUAN}

Tulzak dan Hillock (1988 dalam Naidoo, 1998) dan Olson dan Haynes (1993 dalam Naidoo, 1998) mengatakan bahwa konsep umum dari pengasuhan adalah perlunya keberadaan baik ayah dan ibu sebagai dasar kebutuhan kepuasan anak dan perkembangan 
yang kuat. Beberapa konsep yang mengkonfirmasi dan menetapkan bidang psikologi perkembangan, telah mendapatkan banyak penelitian terkait keluarga dengan orang tua tunggal. Terkait model yang sedikit, keluarga dengan orang tua tunggal dikonsepkan sebagai tidak lengkap dan menyimpang; peran ibu tunggal dilihat sebagai masalah dalam hal tersebut.

Tantangan yang dihadapi ibu tunggal sebagai kepala keluarga memelukan banyak tenaga karena mereka menghadapi tanggung jawab ganda, dimana mereka tidak hanya sebagai tulang punggung tetapi juga sebagai pengatur dan pendidik anak-anak mereka. Tantangan yang sering dihadapi ibu tunggal adalah masalah finansial, stress secara emosional, masalah fisik dan psikologis, tantangan dalam menyiapkan pendidikan bagi anakanak, mengasuh dan menyayangi, dan juga stigma negatif yang diarahkan pada mereka. Ibu tunggal juga mengahadapi beragam tantangan sebagai kepala keluarga sama seperti mereka harus menyulap persaingan prioritas dalam menyediakan kebutuhan finansial dan mengatur pendidikan anak-anak mereka (Faizah Abd Ghani \& Azian Abd Aziz, 2013)

Ibu yang bercerai dan mejadi ibu tunggal, harus mengatasi banyak tekanan. Salah satu masalah yang utama bagi ibu-ibu yang mengasuh anak adalah finansial yang terbatas; situasi yang sering memburuk jika ayah gagal membiayai kebutuhan anak. Penelitian pada 429 catatan pengadilan, Rettig, dkk (1991 dalam Olson \& De Frain, 2003) menemukan bahwa keputusan pengadilan hanya terpenuhi 58\% saja terkait kebutuhan anak-anak jika dibandingkan dengan dukungan bagi warga miskin. Seperti telah diduga sebelumnya, orangtua yang tinggal dengan anak-anak menghabiskan lebih banyak pendapatan mereka (baik ayah atau ibu) dalam memenuhi kebutuhan anak dibandingkan dengan orangtua yang tidak tinggal dengan anak (Olson \& De Frain, 2003).

Dalam bukunya, Olson dan DeFrain (2003) menyebutkan hasil dari wawancara yang mereka lakukan, bahwasannya kesendirian juga menjadi masalah yang umum terjadi pada ibu tunggal. Salah satu ibu berkomentar, "Kepedihan yang sebetulnya kami rasakan adalah tentang mengatur kenyataan bahwa ayah tidak bersama dengan kami dalam membagi tugas sehari-hari dalam kehidupan berkeluarga". "Saya sangat kasihan pada anak saya ketika saya melihat kesendirian mereka ketika jauh dari ayah dan teman lama. Saya menyesal meminta banyak waktu untuk bercakap dan meminta dukungan dari mereka dalam kesendirian saya ketimbang apa yang dapat mereka berikan", kata seorang ibu. Beberapa ibu khawatir akan datang hari dimana mereka semakin tidak mengenali ayah mereka. Beberapa ibu yang bercerai dan mendapatkan hak asuh anak juga menyesali hilangnya hubungan yang baik 
dengan kakek nenek. Secara berkala, anak pulang ke rumah dengan perasaan bingung karena penyesalan dan menunggu untuk disalahkan atau dibenci (Olson \& De Frain, 2003)

Penelitian yang dilakukan oleh Sultan, Shohaib, Saeed, Dildar, dan Khan (2012) menemukan bahwa "ibu tanpa ayah di rumah mengalami penderitaan di luar apa yang anda bayangkan. Sebelumnya, ayah adalah tulang punggung. Sehingga, ibu tunggal mengalami kemiskinan" (Perdew, 2006 dalam Sultan, dkk, 2012). Posisi ekonomi para wanita yang tinggal sendiri dengan anak-anak sangatlah genting dan menjadi alasan utama bagi kemiskinan ibu tunggal (OECD, 1990 dalam Sultan, dkk, 2012). Sehingga, penelitian ini bertujuan untuk mengetahui strategi coping dan distorsi kognitif pada ibu tunggal serta hubungan antara strategi coping dan distorsi kognitif pada ibu tunggal.

Di Indonesia, rumah tangga dengan ibu tunggal adalah fenomena biasa pada era modern. Rumah tangga dengan ibu tunggal adalah mereka yang membesarkan anak-anak mereka sendirian tanpa ada bantuan dari orang lain atau suami. Menjadi ibu tunggal tidaklah mudah,kerena ibu tunggal memiliki banyak tanggung jawab dalam mengemban banyaknya peran, terutama dalam membesarkan anak (Ariati \& Wahyuningsih, 2008). Gading (dalam Aprilia, 2013) mengatakan bahwa ibu tunggal mempunyai tanggung jawab untuk melindungi, membimbing, dan mengasihi anak-anak mereka sendirian tanpa adanya pasangan dalam waktu yang lama atau permanen. Ibu tunggal juga harus menyulap banyak tanggung jawab, seperti finansial, pekerjaan rumah, dan pengasuhan, dan mereka tidak mendapatkan dukungan pasangan untuk berbincang, berkooperasi, dan merasa nyaman yang dapat berkontribusi pada stress (Malik \& Irshad, 2012).

Repulika (2005) melaporkan cerita Titi (bukan nama sebenarnya) yang menjadi orang tua tunggal setelah suaminya meninggal pada tahun 1996. Titi merasa terdorong untuk melakukan semuanya seorang diri, dimana ia adalah kepala keluarga dan ibu bagi anak-anak. Semenjak suami meninggal, hidup terasa berat, terutama ketika harus memikul peran sebagai orang tua tunggal dari dua anak yang harus ia besarkan. Tidak ada yang berharap menjadi ibu tunggal (orang tua tunggal). Keluarga yang utuh dan lengkap adalah dambaan setiap orang. Bagaimanapun, terkadang, takdir berkata lain. Menjadi orang tua tunggal tidak mudah, terutama pada wanita yang ditinggal oleh suami karena kematian. Setidaknya, memerlukan usaha lebih dalam membesarkan anak, termasuk dalam memenuhi kebutuhan keluarga (Ariati \& Wahyuningsih, 2008). Menjadi ibu tunggal mengarahkan ibu pada situasi untuk mempunyai peran ganda, sebagai ibu dan ayah. Lebih jauh, ibu tungal juga mmepunyai dua figur: sebagai ibu yang lunak pada anak-anak dan sebagai ayah yang cenderung tegas dan mengontrol aturan dan larangan di keluarga (Akmalia, tt). Ibu tunggal 
perlu memainkan dua peran pada anak-anak mereka dan pada lingkungan sosial (Aprilia, 2013).

Banyak berita yang melaporkan tentang ibu tunggal dari Finer (dalam Aprilia, 2013) bahwa keluarga dengan orang tua tunggal menghadapi banyak permasalahan seperti terkucilkan, kesendirian, kesulitan ekonomi, dan tambahan tekanan untuk membesarkan anak-anak dan mempunyai tanggung jawab diatas kemampuan. Lingkungan dengan keluarga ibu tunggal juga menjadi beban terkait asumsi negatif. Ibu tunggal yang tinggal hanya dengan anaknya, sering dianggap sebagai sosok yang kesepian dan perilakunya menjadi sorotan. Bukan hal yang jarang jika ibu tunggal menjadi bahan perbincangan ketika mereka berhubungan dengan laki-laki. Seperti cerita Y yang mendapat rumor mengganggu suami orang karena laki-laki tersebut adalah pelanggan tetap. Ini membuat $\mathrm{Y}$ merasa serba salah dan mendapat pelajaran bahwa ia perlu berhati-hati ketika berinteraksi dengan lawan jenis (Ariati \& Wahyuningsih, 2008).

Masih ada banyak masalah lainnya yang dihadapi para orang tua tunggal karena meninggalnya suami. Sebagai tambahan terkait paradigm negatif dari komunitas, ibu tunggal juga menghadapi permasalahan berat yang berlanjut pada kesusahan membesarkan anakanak yang sebelumnya bergantung pada suami dan sekarang harus berjuang sendiri dalam membesarkan dan mendidik anak-anak. Pada mulanya, ia membesarkan anak dengan suami, dan kebutuhan sehari-hari ditanggung oleh suami, tapi kini ibu tunggal harus berdiri sendiri tanpa bantuan dari suami. Ibu tunggal yang dulunya bergantung pada suami kini harus mampu mendukung keluarganya sendiri. Ini tidaklah mudah dan membutuhkan kekuatan dan semangat untuk membesarkan anak-anak dari kesulitan. Banyak ibu tunggal yang didorong untuk mencari penghasilan sendiri guna bertahan hidup. Seperti halnya kisah seorang ibu beranak tiga, dimana suaminya menninggal enam tahun yang lalu, ia berusaha sangat kuat untuk menghidupi anak-anaknya dan untuk keperluan sekolah. Ia mengaku bahwa ia harus bekerja semenjak suaminya meninggal; ia mengatakan bahwa ini sangat berat, karena sebelumnya ia tidak pernah bekerja dan hanya bergantung pada suami. Sebagai tambahan, ibu tunggal sering dianggap kesepian oleh masayarkat dan juga sering didekati oleh pria yang ingin menikahi. Ini bukanlah kasus yang sedikit, perlu adanya cara khusus dalam menolak tetapi tetap menjaga hubungan baik dengan lawan jenis (Ariati \& Wahyuningsih, 2008).

Pitasari dan Cahyono (2014) menyimpulkan bahwa, menjadi ibu tunggal merupakan sebuah tekanan, ibu tunggal merasa kurang kompeten tanpa adanya pasangan dan keharusan mengurus rumah tangga dan anak-anak sendirian. Akan tetapi, ada beberapa strategi coping 
yang dapat digunakan ibu tunggal dalam mengahadapi tekanan. Coping adalah usaha untuk merubuah pikiran atau perilaku dalam mengatur tuntutan dari dalam maupun dari luar yang terasa sulit dan melebihi kemampuan individu (Pitasari \& Cahyono, 2014).

Lazarus dan Folkman (1984) mendefinisikan coping sebagai perubahan yang konstan secara kognitif dan perilaku sebagai usaha untuk mengatasi tuntutan yang spesifik dari eksternal maupun internal yang dapat dinilai dari banyak atau tidaknya sumber daya yang dimiliki setiap individu. Belal dkk (dalam Meguellati \& Ali, 2011) mengartikan strategi coping sebagai cara yang dilakukan invididu, kelompok atau organisasi untuk meminimalisir dampak dari stress. Breakwell (dalam Meguellati \& Ali, 2011) mengatakan bahwa strategi coping adalah "setiap aktivitas, dalam pemikiran ataupun perilaku, yang memiliki tujuan untuk menghilangkan atau memodifikasi ancaman bagi identitas".

Sarafino (dalam Pitasari \& Cahyono, 2014) menyebutkan bahwa coping adalah proses yang dilakukan individu dalam mengatur jarak antara kebutuhan dan sumber daya ketika mengalami perasaan tertekan. Coping adalah cara untuk membenarkan atau mendominasi permasalahan. Coping juga membantu individu dalam merubah persepsi terhadap pemikiran yang tidak tepat, untuk bertoleransi atau menerima ancaman dan bahaya, melarikan diri, atau untuk menghindari situasi tersebut.

Garcia, Franco, dan Martinez (2007) menyimpulkan bahwa fokus pada adaptif dan maladaptif meliputi penyelesaian masalah, menghindari masalah, dan mengkritik diri sendiri. Menyelesaikan masalah adalah strategi secara kognitif dan perilaku yang bertujuan untuk mengeliminasi tekanan dengan cara memodifikasi situasi yang menimbulkan tekanan; menghindari masalah adalah strategi yang meliputi penolakan dan menghindari pikiran atau perilaku yang berhubungan dengan kejadian-kejadian yang menekan; dan mengkritik diri sendiri adalah strategi berdasarkan menyalahkan diri sendiri dan mengkritik diri terhadap situasi menekan yang terjadi atau kurangnya kemampuan dalam mengelola situasi tersebut.

Fungsi dari coping yang berfokus pada masalah adalah untuk merubah hubungan antara orang dan lingkungan yang bermasalah dengan cara bertindak pada lingkungan atau diri sendiri (Lazarus, 1993). Coping yang berfokus pada masalah adalah pendekatan yang mengarahkan pada kecenderungan untuk mengurangi sumber tekanan atau meningkatkan sumber daya (Pitasari \& Cahyono, 2014). Persepsi Taylor (dalam Ariati \& Wahyuningsih, 2008) mendefinisikan bahwa coping yang berfokus pada masalah sebagai perilaku mengatasi yang fokus pada masalah, bagaimana menyelesaikan masalah atau melakukan sesuatu untuk mengurangi sumber masalah, menggunakannya untuk menghilangkan masalah atau tekanan yang dirasakan dengan mencari solusi secara langsung. 
Fungsi dari coping yang berfokus pada emosi adalah antara untuk a) memperhatikan hubungan antara tekanan dan lingkungan (seperti dalam kewaspadaan atau penghindaran) atau b) memaknai hubungan atas apa yang terjadi, yang meringankan tekanan meskipun kondisi aktualnya dari hubungan tersebut tidak berubah. Untuk pilihan yang kedua tersebut adalah melibatkan penilaian ulang yang lebih buruk atau kurang mengancam, seperti digambarkan, misalnya, dalam penyangkalan atau penyempitan (Lazarus, 1993). Coping yang berfokus pada emosi bertujuan untuk mengontrol respon emosi terhadap situasi penyebab stress (Pitasari \& Cahyono, 2014).

Garcia (2007 dalam Salhah, Amla, Zuria, Jamil, \& Saedah, 2011) menyebutkan aspekaspek dari strategi coping yang dibagi menjadi tiga; fokus pada mengatur emosi, fokus pada adaptif dan maladaptif, dan fokus pada emosi. Dari ketiga aspek tersebut terciptalah dimensi dari coping yang terlah diterjemahkan oleh Salhah, dkk., (2011) yang terdiri dari: pemecahan masalah, strukturisasi kognitif, ekspresi emosi, dukungan sosial, menghindari masalah, pengharapan, mengkritik diri sendiri, dan menarik diri dari sosial.

Cara berpikir individu berkaitan erat dengan bagaimana kepribadian individu tersebut yang mengarahkan pada strategi coping yang dipilih dan ada atau tidaknya kecenderungan distorsi kognitif. Kata 'distorsi kognitif' seperitnya telah diadopsi dari literatur terapi kognitif untuk masalah deperesi. Pada bahasan ini, kata tersebut digunakan untuk mendeskripsikan 'Isi pemikiran idiosyncratic (istimewa) menunjukkan konseptualisasi yang menyimpang atau tidak realistis' (Maruna \& Mann, 2006). Beck (dalam Maurna \& Mann, 2006) menggunakan kata kognisi untuk mengarahkan pada 'pemikiran spesifik, seperti interpretasi, memerintahkan diri sendiri atau mengriktik diri sendiri', tambahan dari kata tersebut juga berarti 'juga digunakan untuk menungkapkan harapan-harapan secara verbal'. Distorsi kognitif juga mengarah kepercayaan yang tidak biasa tentang diri; seperti menyalahkan diri sendiri, mengkritik diri sendiri, tidak ada pertolongan dan tidak ada harapan (Zainah, Rohany, Asmawati, Rozainee, \& Fatimah, 2014).

Distorsi kognitif juga diartikan sebagai "cara yang tidak akurat atau bias dalam memperhatikan atau memberi makna pada suatu pengalaman" (Besta, Barczak, Lewandowska-Walter, \& Dozois, 2014). Abel dan koleganya (dalam Maruna \& Mann, 2006) melihat distorsi sebagai hasil dari usaha untuk mengurangi ketidaknyamanan subjektif terhadap perilaku yang dirasa tidak dapat diterima oleh orang lain. Pada terapi perilaku emosi rasional dari Ellis (dalam Rusni, Rohany, Wan Shahrazad, \& Fatimah, 2013), distorsi kognitif mengarah pda sikap merasionalkan, pikiran atau kepercayaan yang berpusat pada 
perilaku diri sendiri atau orang lain. Individu dengan distorsi kognitif menerima sesuatu, orang dan perilaku dalam cara yang terdistorsi.

Istilah distorsi kognitif digunakan untuk mendeskripsikan kepercayaan yang tidak biasa tentang diri, seperti menyalahkan diri, mengkritik diri, tidak berdaya, dan tidak ada pertolongan, yang menunjukkan secara nyata bagaimana pemikiran-pemikiran tersebut dapat terdistorsi (Salhah, dkk., 2011).

Karakteristik distorsi kognitif berikut dikembangkan oleh Briere (2000):

1. Mengkiritk diri sendiri mengukur tendensi untuk mengkritik atau mengurangi nilai pada diri sendiri, baik dari internal maupun dari orang lain. Individu yang cenderung mengkritik diri sendiri melihat diri mereka sendiri secara negatif dan menunjukkan pemikiran negatif secara terus menerus terkait keburukan mereka dan ketidakmampuan dalam menerima sesuatu. Pada beberapa individu, hal ini dapat ditunjukkan dengan membenci diri sendiri atau tidak menyukai diri sendiri, menunjukkan cukup banyak kemarahan yang diarahkan pada diri sendiri.

2. Menyalahkan diri sendiri diketahui dengan sejauh mana individu menyalahkan diri mereka sendiri ke arah yang negatif dan pada kejadian yang tidak diinginkan yang telah terjadi dalam hidupnya. Individu dengan tingkat menyalahkan diri sendiri tinggi cenderung memaknai kehidupan secara negatif, percaya bahwa mereka bertanggung jawab atas hal-hal negatif yang terjadi.

3. Tidak ada pertolongan merupakan persepsi yang membuat individu tidak mampu mengontrol atau mempengaruhi hal-hal yang penting. Berasumi bahwa usaha yang dilakukan untuk merubah hal-hal yang tidak diinginkan atau suatu masalah pasti akan gagal, terkadang menuntun individu menjadi lebih pasif atau menghindar dari menghadapi tantangan atau bahaya.

4. Tidak berdaya merupakan suatu kondisi yang dipercaya bahwa individu mempunyai masa depan yang suram dan menuju pada penderitaan atau kegagalan. Ditunjukkan dengan sikap pesimis, cenderung menghindari kegiatan yang memerlukan hasil yang positif. Seringkali mengarahkan individu pada depresi.

5. Preoccupation with danger (PWD) mengarahkan individu pada melihat dunia sebagai tempat yang berbahaya, terutama pada kaitannya terhadap hubungan dengan orang lain. Individu dengan tingkat PWD yang tinggi cenderung sangat sensitive terhadap bahaya dan menganggap bahwa kejadian tertentu mempunyai resiko secara emosional maupun secara fisik. Hal ini dapat mengarahkan individu pada keinginan untuk menghindar tantangan atau kekerasan. 
Beberapa penelitian terkait ibu tunggal menyimpulkan bahwa, para ibu tunggal mengalami tekanan. Seperti penelitian yang diungkap oleh Pitasari dan Cahyono (2014) bahwasannya, mereka menemukan bahwa ada beberapa sumber tekanan yang menjadikan ibu tunggal mengalami stress. Untuk menghadapi tekanan tersebut, para ibu tunggal melakukan beberapa strategi coping yang berbeda. Seperti contoh dari dua responden berikut, dimana responden pertama tidak mampu menghadapi tekanan sehingga ia memilih untuk meminum obat tidur semenjak kepergian suaminya. Berbeda dengan responden kedua yang mampu menghadapi tekanan dan memilih untuk lebih mendalami agama, terlebih kehadiran anak-anak yang ada disampingnya, mampu membantunya menghadapi berbagai tekanan (Pitasari \& Cahyono, 2014).

Distorsi kognitif berkaitan dengan stress dan depresi. Menurut sejarah, distorsi kognitf berintegrasi dengan teori depresi dari Beck. Ibu tunggal yang ditinggal oleh suaminya karena kematian atau perceraian seringkali mengalami tekanan-tekanan yang disebabkan oleh perubahan kehidupan yang mendadak. Ibu tunggal seringkali dilaporkan memiliki tingkat stress yang tinggi dan adanya episode depresi dibandingkan dengan ibu menikah (Hashimah, Azman, dan Noraida, 2015).

Dua uraian di atas menunjukkan bahwa, seringkali ibu tunggal mengalami distorsi kogntif dan melakukan beberapa strategi coping dalam menghadapi tekanan yang dialami. Sehingga, penelitian ini ditujukan untuk mengetahui strategi coping apa yang digunakan ibu tunggal dan jenis distorsi kognitif pada ibu tunggal. Paradigma tentang ibu tunggal di masyarakat terkadang tidak baik dan mereka menghadapi hidup yang penuh tekanan yang membuat ibu tunggal perlu berjuang. Dimana hipotesis dari penelitian ini adalah, adanya hubungan yang signifikan antara distorsi kognitif dengan strategi coping pada ibu tunggal.

\section{METODE}

\section{Definisi Operasional}

Strategi coping adalah perilaku yang dilakukan individu ketika menghadapi suatu tekanan. Strategi coping terdiri dari delapan faktor, yaitu penyelesaian masalah, menstruktur ulang kognitif, ekspresi emosional, dukungna sosial, menghindari masalah, penuh pengharapan, mengkritik diri sendiri, dan menjauhi sosial. Sedangkan distorsi kognitif berkaitan dengan stress dan depresi yang mengarahakan individu berpikir secara tidak biasa yang memiliki lima gejala, yaitu menyalahkan diri sendiri, mengkritik diri sendiri, tidak ada harapan, tidak ada pertolongan, dan PWD. 


\section{Subjek Penelitian}

Penelitian ini memiliki responden 100 orang ibu tunggal (baik karena alasan bercerai maupun karena suami meninggal) yang berasal dari komunitas-komunitas ibu tunggal yang ada di Yogyakarta. Setiap responden diberikan satu set kuesioner yang berisi skala strategi coping dan skala distorsi kognitif.

\section{Alat Pengumpul Data}

Peneltian ini menggunakan satu set kuesioner yang berisi Coping Strategy Inventory (CSI) dan Cognitive Distortion Scale (CDS). Coping Strategy Inventory (CSI) terdiri dari 40 aitem yang awalnya dibuat oleh Cano Garcia pada 2007 (dalam Salhah, dkk., 2011). Skala ini diadaptasi dan diterjemahkan dari Spanish Version of Coping Strategies. Responden diminta untuk menjawab 40 aitem yang mengukur cara coping berdasarkan tiga strategi; fokus pada mengatur emosi, fokus pada adaptif dan maladaptive, dan fokus pada emosi. Lima poin skala Likert dari 1-5 digunakan untuk mengindikasi rating dari setiap aitem. Delapan faktor utama (penyelesaian masalah, menstruktur ulang kognitif, ekspresi emosional, dukungna sosial, menghindari masalah, penuh pengharapan, mengkritik diri sendiri, dan menjauhi sosial) diidentifikasi sebagai dimensi dari coping (Salhah, dkk., 2011).

Cognitive Distortion Scale (CDS) dari Briere adalah skala dengan 40 aitem yang mengukur lima gejala kognitif yang mengarah pada distorsi, seperti menyalahkan diri sendiri, mengkritik diri sendiri, tidak ada harapan, tidak ada pertolongan, dan PWD, yang ditemukan pada individu-individu yang pernah menjadi korban kejadian tertentu. Semua faktor memiliki konsistensi internal yang baik dan validitas konvergen dengan ukuran distorsi kognitif lain pada beberapa sampel klinis dan non klinis (Salhah, dkk., 2011). Aitem CDS diukur menggunakan 5 skala Likert (1= tidak pernah sampai $5=$ selalu). Dengan kemungkinan skor total adalah 40-200.

Distribusi faktor dari semua instrumen mengartikan bahwa skor mentah dari setiap subskala menunjukkan mayoritas faktor yang mempengaruhi responden. Ini berarti bahwa semakin tinggi skor dari setiap subskala merupakan faktor yang biasa digunakan oleh respondne. Peneliti juga dapat menentukan berapa banyak responden yang menggunakan setiap subskala dari kedua instrumen tersebut.

\section{Metode Analisis Data}

Penelitian ini menggunakan pendekatan kuantitaf yang menggunakan metode survey dalam mendeskripsikan strategi coping dan distorsi kognitif pada ibu tunggal yang ada di 
Yogyakarta. Penelitian ini juga dilakukan untuk mengetahui korelasi antara dua varibel tersebut. Penelitian ini menggunakan serangkaian kuesioner dalam pengambilan data dari responden.

Terkait dengan pendekatan, pendekatan survey digunakan untuk menunjukkan ratarata dari karakteristik individu (demografik variabel) dan pemikiran, penialaian, serta perasaan secara akurat dan efisien. Sebagai tambahan, hubungan prediktif dapat dilihat dengan cara mencari hubungan antar variabel (Shaughnessy, Zechmeister, \& Zechmeister, 2015). Pendekatan korelasi adalah metode terbaik untuk menemukan tujuan secara deskriptif dan prediktif. Bukti korelasi membantu peneliti untuk membuat prediksi untuk variabelvariabel yang berkolerasi (Shaughnessy, dkk., 2015). Independent t-test, ANOVA, dan Pearson Correlation menggunkanan bantuan aplikasi IBM SPSS Statistic dilakukan untuk menganalisis data.

\section{HASIL DAN PEMBAHASAN}

Skor tertinggi dari strategi coping yang ditemukan dalam penelitian ini adalah penstrukturan ulang secara kognitif pada ibu tunggal, dimana strategi coping ini memodifikasi makna dari situasi yang menekan (Garcia, dkk., 2007). Penstrukturan ulang secara kognitif adalah salah satu dari delapan faktor yang digunakan dalam penelitian ini, yaitu pemecahan masalah, penstrukturan kognitif, ekspresif secara emosional, dukungan sosial, menghindari masalah, mengharap, mengkritik diri, dan menarik diri secara sosial.

\begin{tabular}{lcc}
\hline Faktor & Frekuensi & Prosentase (\%) \\
\hline Pemecahan masalah & 18 & 14.75 \\
Mengkritik diri & 3 & 2.46 \\
Ekspresif secara emosinal & 1 & 0.82 \\
Penuh harapan & 21 & 17.21 \\
Dukungan social & 5 & 4.1 \\
Penstrukturan kognitif & 67 & 54.92 \\
Menghindari masalah & 7 & 5.74 \\
Menarik diri secara sosial & 0 & 0 \\
\hline Total & $\mathbf{1 2 2}$ & $\mathbf{1 0 0}$ \\
\hline
\end{tabular}

Penelitian yang dilakukan Compas dan Williams (1990) menemukan bahwa secara spesifik, ibu tunggal menggunakan strategi coping yang berkaitan dengan penerimaan tanggung jawab dari masalah dan secara positif mampu meninjau kembali situasi yang menekan dibandingkan dengan ibu yang masih menikah. Strategi coping ini mungkin menunjukkan kenyataan kehidupan ibu tunggal. Tanpa pasangan untuk berbagi tanggung jawab dari tekanan kehidupan sehari-hari, ibu tunggal dipaksa untuk menerima tanggungan yang lebih besar. Bagaimanapun, sampel ibu tunggal pada penelitian Compas dan Williams terlihat telah mampu menyeimbangkan pendekatan realistis dalam mengatasi tekanan dengan 
cara fokus pada aspek positif dari situasi menekan yang mereka hadapi (Compas \& Williams, 1990). Ini berarti bahwa fokus pada faktor positif, ibu tunggal memodifikasi makna dari situasi yang menekan, dan penelitian ini mendukung penelitian yang telah disebutkan diatas.

Sedangkan pada distorsi kognitif yang ditemukan pada ibu tunggal, mayoritasnya adalah PWD. PWD adalah salah satu dari lima faktor yang digunakan pada penelitian ini, yaitu mengkritik diri sendiri, menyalahkan diri sendiri, tidak mendapat pertolongan, tidak berdaya, dan PWD. PWD serupa dengan asumsi negative yang diteliti oleh Ariati dan Wahyuningsih (2008). Penelitian Ariati dan Wahyuningsih (2008) menemukan bahwa ibu tunggal dalam masyarakat sering mendapat tekanan berupa asumsi negative. Ibu tunggal yang tinggal dengan anak-anak dianggap kesepian, dan perilakunya selalu diawasi. Ibu tunggal sering menjadi subjek gosip ketika mereka melakukan kegiatan dengan laki-laki. Sebagai contoh, seorang ibu tunggal berinisal $\mathrm{Y}$ yang sering digosipkan mengambail suami orang hanya karena banyak lelaki yang sering membeli barang di warungnya (Ariati \& Wahyuningsih, 2008). Hal ini mendukung hasil penelitian ini, dimana distorsi kognitif pada ibu tunggal mayoritas adalah PWD; mereka merasa tidak aman ketika berada di masyarakat. Mereka merasa takut dan tidak nyaman karena gosip. Meskipun begitu, mayoritas responden pada penelitian ini memiliki tingkat yang rendah pada distorsi kognitif. PWD dan asusmi negatif yang dideskripsikan diatas berhubungan dengan pengeritan PWD menurut Briere (2000), di mana PWD adalah tendensi seseorang dalam memandang dunia sebagai tempat yang membahayakan, terutama dalam hal interaksi dengan orang lain.

\begin{tabular}{lcc}
\hline Faktor & Frekuensi & Prosentase (\%) \\
\hline Mengkritik diri sendiri & 13 & 10.32 \\
Menyalahkan diri sendiri & 18 & 14.29 \\
Tidak ada pertolongan & 38 & 30.16 \\
Tidak ada harapan & 11 & 8.73 \\
Preoccupation of danger (PWD) & 46 & 36.5 \\
\hline Total & $\mathbf{1 2 6}$ & $\mathbf{1 0 0}$ \\
\hline
\end{tabular}

Untuk mengetahui hubungan antara strategi coping dan distrosi kognitif menggunakan Pearson product-moment, hasilnya menunjukkan bahwa terdapat hubungan antara distorsi kognitif dan strategi coping dengan skor $\mathrm{r}=0,314$.

** correlation is significant at the 0.01 level (2-tailed)

\section{PENUTUP}

Hasil dari penelitian ini menunjukkan bahwa mayoritas ibu tunggal yang berasal dari komunitas di Yogyakarta memiliki pengaturan ulang kognitif sebagai strategi coping dan 
PWD sebagai distorsi kognitif. Lebih lanjut lagi, terdapat hubungan anatara distorsi kognitif dan strategi coping pada ibu tunggal. Diharapkan, penelitian ini dapat bermanfaat bagi ibu tunggal, konselor, Kementerian, dan masayarkat sekitar untuk lebih memahami strategi coping dan distorsi kognitif pada ibu tunggal.

\section{DAFTAR PUSTAKA}

Akmalia. (tanpa tahun). Pengelolaan Stress pada Ibu Single Parent. Yogyakarta: Universitas Ahmad Dahlan.

Aprilia, W. (2013). Resiliensi dan Dukungan Sosial pada Orangtua Tunggal (Studi Kasus pada Ibu Tunggal di Samarinda). eJournal Psikologi, 1 (3), 268-279.

Ariati, L., \& Wahyuningsih, H. (2008). Coping Behavior pada Ibu Rumah Tangga yang Memutuskan Tidak Menikah Lagi Karena Suaminya Meninggal. (Naskah Publikasi). Yogyakarta: Universitas Islam Indonesia.

Briere, J. (2000). Cognitive Distortion Scales John Briere Ph.D. John Briere Ph.D (www.johnbriere.com). accessed: 8 October 2015

Compas, B. E., \& Williams, R. A. (1990). Stress, Coping, and Adjustment in Mothers and Young Adolescents in Single- and Two- Parent Families. American Journal of Community Psychology, 18, 525-545.

Faizah, \& Azian. (2013). Profile of Single Mother in Southern Malaysia and Issues Afflicting Their Lives. British of Journal of Art and Social Science, 16, 197-206.

Garcia, F. J., Franco, L. R., \& Marinez, J. G. (2007). Spanish Version of Coping Strategies Inventory. Actas Esp Psiquiatr, 35, 29-39.

Hashimah, I., Azman, \& Noraida. 2015. "Stress, Roles, and Responsibilities of Single Mothers in Malaysia". EDP Sciences. p 1-7.

Kotwal, N., \& Prabhakar, B. (2009). Problems Faced by Single Mothers. Journal of Social Science, 21 (3), 197-204.

Lazarus, R. S. (1993). Coping Theory and Research: Past, Present, and Future. Psychosomatic Medicine, 5, 234-247.

Lazarus, R. S., \& Folkman, S. (1984). Stress, Appraisal, and Coping. New York: Springer Publisher Company.

Malik, T. A., \& Irshad, N. (2012). Parental Depression, Stress, Anxiety and Childhood Behavior Problems among Single Parent Families. JPPS, 9 (1), 10-14.

Maruna, S., \& Mann, R. E. (2006). A Fundamental Contribution Error? Rethinking Cognitive Distortion. Legal and Criminological Psychology, 11, 155-177.

Meguellati, \& Ali. (2011). The Role of Religiousity as a Coping Strategy in Coping with Work-Family Conflict: The Case of Malaysian Women in Academia. International Journal of Social Science and Humanity, 1(1), 80-85. 
Naidoo, P. (1998). The Experience of Divorced Mother as Single-Parents. Psychology in Society, 23, 17-34.

Olson, D. H., \& De Frain, J. (2003). Marriages and Families: Intimacy, Diversity and Strenght Fourth Edition. New York: The McGraw Hill.

Pitasari, A. T., \& Cahyono, R. (2014). Coping pada Ibu yang Berperan Sebagai Orangtua Tunggal Pasca Kematian Suami. Jurnal Psikologi Pendidikan dan Perkembangan, 3, $37-41$.

Republika. (2014, 14 November). Tingkat Percerain Indonesia Meningkat Setiap Tahunnya. Diakses dari www.nasional.republika.co.id. 5 Januari 2015.

Salhah, Amla, Zuria, Jamil, \& Saedah. (2011a). Cognitive Distortion, Depression, and Self Esteem among Adolescents Rape Victims. World Applied Sciences Journal (Learning Innovation and Intervention for Divers Learners, 14, 67-73.

Salhah, Sapora, Farhana, D., \& Perdani, R. (2011b). Strategi Daya Tindak Versi Bahasa Melayu. Perkama International Counseling Convention 2011. Nilai: PERKAMA.

Sharf, R. S. (2008). Theorist of Psychotherapy and Counseling: Concepts and Cases, Fourth Edition. USA: Thomson Brooks/Cole.

Shaughnessy, J. J., Zechmesiter, E. B., \& Zechmeister, J. S. (2015). Research Method in Psychology, Tenth Edition. New York: McGraw Hill Education.

Sultan, T., Shoaib, M., Saeed, Y., Dildar, S., \& Khan, S. (2012). Problem of Single Mothers and State Provisions: A Case of Sweden and Denmark. Middle-East Journal of Scientific Research, 11(7), 988-991.

Zainah, Rohany, Asmawati, Rozainee, \& Fatimah. 2014. Family Functioning, Cognitive Distortion and Resilience among Clients under Treatment in Drug Rehabilitation Centres in Malaysia. Procedia-Social and Behavioral Sciences, 140, 150-154. 